\title{
Impact of Globalization on Organizational Form: Die Away of Open Air Movie Theatres in Turkey
}

\author{
R. Arzu Kalemci
}

\begin{abstract}
Those asserting that globalization has a 'convergence' effect on institutional field point that, with globalization, models and practices acknowledged as 'best practices' will move from where they are institutionalized to other countries. With the late of 1980 s, Turkey met with the American-origin 'multiplex' movie theatres. The main purpose of this study is to examine the expansion of 'multiplex' form of movie theatres and how such expansion affected the reduction in the number of previously existing forms such as open air movie theatres in Turkey. Based on the data of Turkish Statistics Institute (TurkStat), numbers and current statuses of 'open-air movie theatres' that previously existed in Turkey are discussed in the research.
\end{abstract}

Index Terms-Globalization, convergence, U.S, movie theatres, turkey.

\section{INTRODUCTION}

The concept of globalization is often used to refer to sharp increases since the mid-1970s in the flow of goods, services, money, people, information and science among countries [1]. Most management researchers associated globalization with modernization and reflected the prosperity and consumer satisfaction in some countries as an outcome of globalization [2]-[3]. The approach, which regards globalization as modernization generally emphasizes that globalization, creates a 'convergence' effect between countries [1]. According to such approach, bureaucratic managements, formal education, protection of civil rights and science will resemble each other among countries with globalization and this will also become rational [4]-[5]. One of the key arguments of the 'convergence' aspect of globalization is that it introduces the 'best practice' to be imitated among countries. With such process, international models and practices are transferred between countries. Accordingly, within the scope of the globalization process, there are core countries (i.e., U.S. and Japan) representing the best practices and there are periphery countries transferring such best models and practices from core countries [6]-[9]. After the practices transferred from outside are adopted by periphery countries, this will lead to a loss of power in actors in domestic context or to less strong states [5]. According to such approach, stronger or more reputable countries of the international system will shape practices of less strong countries or weaken their legitimacies [10]. On the other hand, as pointing to a specific country instead of strong states, the term 'Americanization' has often been used to discuss the

Manuscript received October 10, 2012; revised December 12, 2012

R. Arzu Kalemci is with the Cankaya University, Faculty of Economics and Administrative Sciences, Department of Management, Eskisehir Yolu 29 Km., Ankara, Turkey, 06810 (e-mail: arzukalemci@ cankaya.edu.tr). convergence process (i.e. [7]-[9]). Main argument of such approach is that the rising success of American industrial

System in the post-Second World War period is effective on the adoption of American administrative practices in particular by European and Japanese companies. At the end of this process, called as 'Americanization', convergence between international organizational practices has gradually increased [11].

With the late of 1980 s, Turkey met with the American-origin 'multiplex' movie theatres. This form of movie theatres, which started to become widespread throughout the world in 1990s, embodies not only multi-screen movie auditoriums, but also food stands and other entertainment activities [12]. On the other hand, this new 'multiplex' movie theatre form has found a place for itself mostly in cities. Because, one of the important conditions required for establishing this form of 'Movie Theater' is to have potential population. Accordingly in this period, some movie theater owners in Turkey split large movie auditoriums into two or more and converted movie theaters into movie complexes [13] and started adapting their own movie theaters to the features of 'multiplex' movie theatres [14]. On the other side, in addition to the old ones, new multiplex movie theaters were built in metropolitan cities, particularly inside the shopping malls [12]. As a consequence of the support provided by U.S, which we can define as the global actor of cinema sector throughout the world, to the expansion of 'multiplex' form of movie theatres, how such expansion affected the reduction in the number of previously existing forms of movie theatres is analyzed in this study. Based on the data of Turkish Statistics Institute (TurkStat) numbers and current statuses of 'open-air movie theatres that previously existed in Turkey are discussed in the research.

\section{METHOD}

In the study, qualitative and quantitative data gathering methods are simultaneously used. Archive scanning and document analysis included books, interviews, magazines and websites on Turkish cinema. The quantitative data were obtained from TurkStat. Since 1978, the TurkStat has been providing statistics on cinemas in all provinces in TurkStat in its publication 'Cultural Statistics'. We accessed all the publications issued by TurkStat since 1978, except for the 1985 publications. In general these data included total number of cinema halls, the number of cinema by class (first, second, third, other) on city basis, number of movie released, number of domestic and foreign movies released, total number of audience and the number of domestic and foreign movie audience 


\section{AMERICAN EFFECT ON THE FORM OF MOVIE THEATRE: TURKEY}

The US has been the most reputable country of the world in the cinema sector from the beginning. With the establishment of Motion Picture Company in 1909, the first film company of the United States, film producers began to turn to foreign markets [14]. The US governments supported the internalization of Hollywood and an act passed in 1918 permitted the studios to collude overseas [15]. Over the next few years, American film companies began to market their own products directly, opening distribution branches in South America, Australia, Far East and European countries, thus taking over the world market [16]. Cinema sector structure in the world generally points to such segregation; although most countries have their own domestic cinema sector, majority of the underdeveloped countries import the movies released in their countries from the West and, mostly, from the USA [17]. The USA holds a significantly dominant position in the world cinema sector, particularly in the field of distribution. To give an example; American movie distributor companies distributed $80 \%$ of the movies, which were distributed in foreign countries in 1990s, in Argentine, one of the countries where national movies get the highest share by $16 \%$ out of the total box office revenues among other Latin American countries [18]. Acland provided important data about the subject in his book titled 'Screen Traffic' [12]. Accordingly, international movie rental prices charged for Hollywood movies in 1993 were higher than those charged for domestic ones. So, American movie companies earned more from other countries than they do from their own country. While the international market share of American cinema sector's box office gross raised by ticket sales was $43 \%$ in 1989, this rate reached $51 \%$ in 1996 , exceeding the domestic market share. Such rates show that American cinema sector earns almost more in the international market than it does in domestic market. USA's creation of global market in cinema sector was not led by the distribution of American movies to other countries. Establishment of American-style movie theater forms in other countries is a part of their global activities. In late 1980s, an American-origin form of movie theatre was introduced to the world. This form of movie theatre goes under the name of 'multiplex' around the world. Such movie theatres embody not only multi-screen movie auditoriums, but also food stands and other entertainment activities [12]. In 1990s, investments were made in venues in some global markets. Such investments include construction of multiplex type movie theatres. In 1990, the USA provided funds to Europe, for the purpose of spreading the construction of American multiplex movie theatres. Italy, Spain, Portugal, the Netherlands, Germany, Finland and Denmark in Europe, as well as Japan, Australia and New Zealand, renovated their movie theatres and increased the number of their stages. It was American distributor companies who invested in movie venues. For example, Warner Brothers (Warner Bros.) and the Paramount/Universal both purchased and constructed movie theatres in Germany. There was a boom in the number of movie theatres in the Southeast Asia and multiplex movie theatre construction contributed to such development. In addition, American movie companies Virgin Cinemas,
Warnel Mycal and AMC (American-Multi Cinemas) built multiplex movie theatres in Japan until the end of 1990s and mostly showed American movies [12]. In brief, globalization of world cinema sector occurred when the USA turned both its movies and form of projection, known as 'multiplex movie theatre', into a global market and expanded them. This American-origin new form of 'multiplex' movie theatres find more place for themselves in cities, which is directly related to the requirement of a potential population needed to build such form of movie theatres and to the fact that each such new form becomes a symbol representing the development of cities [19]. Multiplex movie theatres have therefore found more places for themselves in metropolitans. For instance, with the introduction of multiplex movie theatres in Australia in mid-1980s, the number of single-screen theatres declined in towns and villages and a few of them remained only in Sydney and its vicinity, later to be structured as multi-screen movie theatres [20].

As the American cinema sector's worldwide dominance gradually increased, 1980 s were crucial in terms of the structuring of Turkish economy. In the 1980s, The Turkish economy underwent a change that also directly concerned the cinema sector. A number of structural regulations were launched in Turkey in 1980, under the name of 'reform program'. This program is based on transforming Turkish economic structure into an open, liberal and market-oriented structure in line with global neo-liberal reforms. The entry of foreign capital to various sectors in Turkey, including cinema sector as part of the structural adjustment program was facilitated and encouraged [21]. Turkey, thus, started to open its doors towards outside. The 'multiplex' movie theatres, which started mushrooming under American influence in 1990s, also became more prevalent in Turkey. Cineplex Odeon, for example, built 12 multiplex movie theatres in Turkey between 1998 and 2000 [12]. Apart from that, some movie theatre owners started adapting 'multiplex' movie theatre features to their own theatres. Particularly in metropolitans, many movie theatres were renovated and equipped with Dolby Stereo or Dolby Digital sound systems featured by multiplex movie theatres [14]. Nevertheless, movie theatre managers split large auditoriums into two or more auditoriums and converted movie theatres into movie theatre complexes [13]. In the interview, one of the cinema operators described those times, where big movie theatres were divided into multiple cinemas as follows:

"There were movie theatres with 750 people capacity; but, afterwards, these began to be divided in to halls of 300 people capacity".

In the ongoing process, the number of such movie theatres increased mostly in locations densely occupied by shopping malls. According to an interview made by Hurriyet newspaper correspondent Vahap Munyar with Adnan Akdemir, Chairman of the Executive Board of AFM Movie Theatres, Adnan Akdemir is known as the first one to make a company with professional identity' out of movie theatres and the 'first movie theatre owner' of Istanbul Stock Exchange (IMKB). In the mentioned interview, Adnan Akdemir added that $40 \%$ of his company's movie theatres were in Istanbul, while the rest were in Ankara and Izmir and 
that these three cities made up the majority of movie goers.

TurkStat drew up its lists on movie theatres in accordance with the 'first class', 'second class', 'third class' and 'other' movie theatres classifications until 1987, however, 'luxury class' movie theatres were added to the aforementioned categories after 1988. 'Luxury class' movie theatres describe multi-screen multiplex movie auditoriums. As can be seen in Fig. 1, 'Luxury class' (or multiplex) movie theatres gradually increase in Turkey since 1987.

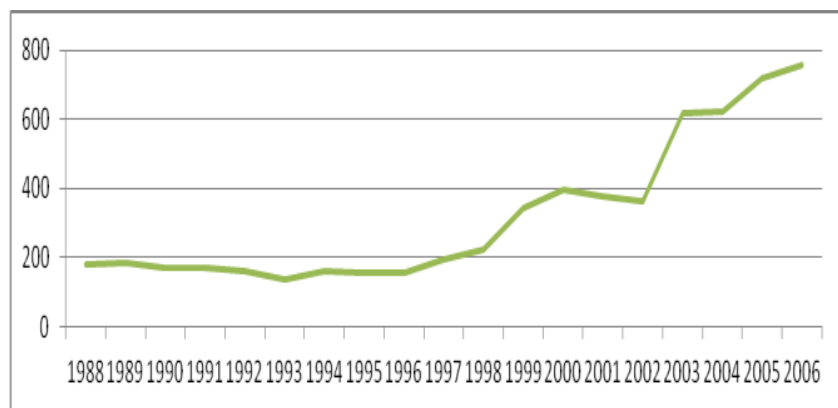

Fig. 1. Number of 'Luxury Class' movie theatres in Turkey: 1988-2006.

On the other hand, as mentioned before, American-origin 'multiplex' movie theatres are mostly built in metropolitans. In Fig. 2, city-based locations of 'luxury class' movie theatres in Turkey in 2003 are pointed on the map of Turkey. The number of 'luxury class' movie theatres present in those cities are also specified on the same map (figures in brackets). Accordingly, although there were totally 186 'luxury class' movie theatres in Turkey in 2003, only 21 cities had 'luxury class' movie theatres. As can be seen on the map of Turkey (Fig. 1), majority of 'luxury class' movie theatres are located in metropolitans. 51 out of 186 'luxury class' movie theatres are in Istanbul, 29 in Ankara and 30 in Izmir. Total number of 'luxury class' movie theatre in these three cities makes up approximately $60 \%$ of the same number for Turkey.

Greece and Australia have also gone through similar experiences. Sifaki analyzed Greek Cinema History in the study titled 'Projections of Popular Culture Through of The Study of Cinema Market in Contemporary Greece' [22]. In 1990s, American foreign distributor countries stepped in the Greek cinema sector. American distribution countries assumed distribution of $90 \%$ of all movies in Greece. This figure hit $92 \%$ in 1992. Movie theatres in Greece were renovated as they were in Turkey and supplementary stages were added to the old traditional movie theatres to turn them into 'multiplex' movie theatres. Multiplex movie theatres became highly popular, particularly among the young population of Athens. In 2001, there were nearly 450 movie theatres in Greece, more than half of them being in Athens. The largest multiplex movie theatre of Athens, "Village Entertainment Park', attracted three and a half million Athenians in its first year of establishment. This figure is three times more than the visitors of Acropolis. On the other hand, American-origin multiplex movie theatres were started to be built in Australia in mid 1980s. In this process, number of multi-screen movie theatres gradually declined in towns and villages. Only a few single-screen movie theatres remained in Sydney and its vicinity, later to be structured as multi-screen movie theatres [20].
TABLE I: NuMBER OF OPEN AIR MOVIE THEATRES, NuMBER OF CitIES WITH Open AIR Movie Theatres AND Percentage of Movie Theatres IN 67 CITIES IN TURKEY: $1978-1986$

\begin{tabular}{|c|c|c|c|}
\hline Year & $\begin{array}{c}\text { Number of } \\
\text { Open-air Movie } \\
\text { Theatres }\end{array}$ & $\begin{array}{c}\text { Number of Cities } \\
\text { With Open-Air } \\
\text { Movie Theatres }\end{array}$ & \% of cities \\
\hline 1978 & 303 & 44 & 65.67 \\
\hline 1979 & 308 & 49 & 73.13 \\
\hline 1980 & 183 & 37 & 55.22 \\
\hline 1981 & 180 & 38 & 56.72 \\
\hline 1982 & 252 & 34 & 50.75 \\
\hline 1983 & 249 & 33 & 49.25 \\
\hline 1984 & 205 & 34 & 50.75 \\
\hline 1986 & 166 & 31 & 46.27 \\
\hline
\end{tabular}

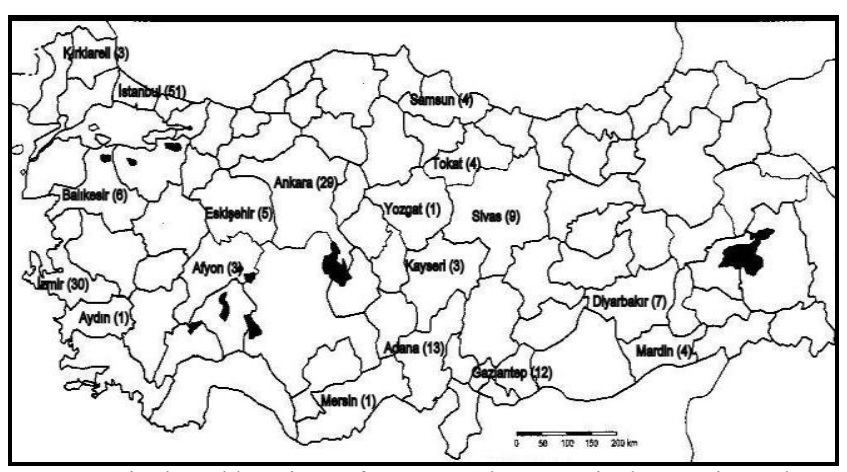

Fig. 2. City based locations of 'Luxury Class' movie theatres in Turkey: 2003.

However, it is known that there were different types of movie theatres in Turkey prior to 1990 s. The most prominent of them is 'open-air' movie theatres. In 1969, there were 1534 open-air movie theatres in Turkey [23]. Additionally, while TurkStat published movie theatres under 'indoor', 'outdoor' (represents open air movie theatres) and 'mobile' titles until 1987, from then onwards, such classification disappeared and records of 'indoor' movie theatres alone were kept. In Table 1, total number of open-air movie theatres in Turkey between 1978 and 1986, the number of cities with open-air movie theatres and percentage of the cities (with movie theatres) in 67 cities to the total number of cities is presented. As can be seen in numbers, open-air movie theatres were not set only in metropolitans, but also in many other places throughout Turkey. Nearly more than half of Turkish cities had open-air movie theatres until 1986. In Greece, on the other hand, with multiplex movie theatres becoming more popular, the number of traditional Greek open-air movie theatres declined. As of 2001, although Greece had 180 outdoor movie theatres out of a total of 450 , only 70 of those outdoor theatres were used [22]. One of the main reasons why TurkStat stopped keeping 'outdoor' movie theatre records was because this movie theatre type slowly dwindled, before vanishing almost completely.

\section{CONCLUSION}

'Convergence' effect of globalization on the cinema sector has been examined. One of the debates about the convergence effect of globalization discussed on and around the 'Americanization' process (i.e. [7]-[9]).This debates mainly emphasize the role of U.S as an imitating factor within the framework of the 'convergence' controversy of globalization. The U.S, as the strongest and most reputable 
country around the world within the international system of cinema sector, has promoted the expansion of 'multiplex' movie theatres, benefitting from its strong competitive advantage in the global market. Multiplex movie theatre forms have been accepted as a part of urban entertainment life and, therefore, they have been mostly built in metropolitans with a certain population potential. In late 1980s, Turkey started to get influenced by such expansion and the number of 'multiplex' form of movie theatres gradually increased. Some other countries are also known to go through such process (i.e. Greece and Australia). On the other hand, it is further known that there were various forms of movie theatres in Turkey during the periods when global impacts did not prevail. One of them is open-air movie theatres. For a certain period of time, open-air movie theatres were set up not only in the metropolitans of Turkey, but also in many places including villages and towns. However, with multiplex movie theatres becoming widespread as a global form, previous movie theatre forms were slowly abandoned. This situation is clearly observed in TurkStat's data on movie theatres. While movie theatres were categorized as 'indoor', 'outdoor', 'mobile' until 1987, from that year onwards, this classification was removed and only the records for 'indoor' movie theatres were tracked. One can observe the absence of outdoor movie theatres in Turkey, except for the very few ones that have been set up merely in holiday villages for long years. This research mainly contributes to debates about the convergence effect of globalization discussed on and around the 'Americanization' process. However this paper also contributes the organizational studies by analyzing the expansion of 'multiplex' form of movie theatres and how such expansion affected the reduction in the number of previously existing forms such as open air movie theatres in Turkey.

\section{REFERENCES}

[1] M. F. Guillen, The Limits of Convergence and Organizational Change in Argentina, South Corea and Spain, Princeton: Princeton University Press, 2001.

[2] T. Levitt, "The Globalization of Markets," Harvard Business Review, vol. 61, pp. 92-102, 1983.

[3] J. Naisbitt and P. Aburdene, Megatrends 2000, New York: Morrow, 1990.

[4] J. W. Meyer, Hannan, National Development and the World System. Education, Economic, and Political Change, University of Chicago Press, 1979, pp. 3-15.

[5] J. W. Meyer, J. Boli, G. M. Thomas, and O. F. Ramirez, "World Society and the Nation State," The American Journal of Sociology, vol. 103, pp. 144-181, 1997.
[6] M. E. Arias and M. Guillén, "The Transfer of Organizational Techniques Across Borders: Combining Neo-Institutional and Comparative Perspectives," in Diffusion and Consumption of Business Knowledge, J. L. Alvarez, Ed. London: Macmillan Press, 1998, pp. $110-137$.

[7] M. L Djelic, Exporting the American Model: The postwar transformation of European Business, Oxford: Oxford University Press, 1998.

[8] M. F. Guillen, Models of management: Work authority, and organization in comparative perspective, Chicago: The University of Chicago Press, 1994.

[9] J. Zeitlin and ve G. Herrigel, Americanization and its Limits: Reworking US Technology and Management in Post-War Europe and Japan, Oxford: Oxford University Press., 2000.

[10] R. Gilpin, The Political Economy of International Relations, Princeton, NJ: Princeton University Press, 1987.

[11] M. Frenkel and Y. Shenhav, "From Americanization to Colonization: The Diffusion of Productivity Models Revisted," Organization Studies, vol. 24, pp. 1537-1561, 2003.

[12] C. R. Acland, Screen Traffic Movies, Multiplexes, and Global Culture, London: Duke University Press., 2005.

[13] A. I. Işığan, "Film Production in der Turkei," MA thesis, Dept. Arts. Turkish, University of Ankara, Ankara, Turkey, 1998.

[14] N. Ulusay, "Globalization and National Film Industries: The Turkish Case,” Boğaziçi Journal, vol. 18, pp. 107-119, 2005.

[15] G. King, New Hollywood Cinema, New York: Columbia University Press, 2002.

[16] K. Thompson and D. Bordwell, Film History: An Introduction, USA: McGraw-Hill, 1994.

[17] J. Delacroix and C. Ragin, "Modernizing Institutions, Mobilization, and Third World Development: A Cross-National Study," The American Journal of Sociology, vol. 84, pp. 123-150, 1978.

[18] P. Hudson, "Foreign Distribs Caugth Coin at Argentine B. O. in '99," Variety, vol. 378, pp. 48, 2000.

[19] M. Athique and D. Hill, "Multiplex cinemas and urban redevelopment in India," Media International Australia, vol. 124, pp. 108-118, 2007.

[20] R. Thorne, Picture Palace Architecture in Australia, Melbourne: Sun Books, 1976.

[21] Ziya Öniş, "Political economy of Turkey in the 1980's: Anatomy of unorthodox liberalism," in State and market: The political economy of Turkey in comparative perspective, Z. Öniş, Ed. İstanbul: Boğaziçi University Press, 1999, pp. 183-196.

[22] E. Sifaki, "Projections of Popular Culture Through the Study of the Cinema Market in Contemporary Greece," in $1^{\text {st }}$ LSE PhD Symposium on Modern Greece "Current Social Sciences Research on Greece", Hellenic Observatory, London School of Economics and Political Science, Paper for the Workshop, 2003.

[23] H. Erkılıç, "Economic Structure of Turkish Cinema and the Influences of Turkish Cinema," Proficiency in Art Thesis, University of Mimar Sinan, İstanbul, Turkey, 2003.

R. Arzu Kalemci received her $\mathrm{PhD}$ in Management and Organization from the Baskent University. She is an Assistant Professor at Cankaya University, Faculty of Economics and Administrative Sciences. She is currently lecturing organizational behavior, organizational theory and business ethics courses. Her areas of research include organizational design, business ethics, and employee behavior. 